This is a postprint version of the following published document:

Antoniou, D., Kornetis, K., Sichani, A.M. and Stefatos, K. (2017). Introduction: The Colonels' Dictatorship and Its Afterlives. Journal of Modern Greek Studies, 35(2) pp. 281-306.

DOI: $10.1353 / \mathrm{mgs} .2017 .0021$

(C) 2017 by The Modern Greek Studies Association 


\title{
Introduction: The Colonels' Dictatorship and Its Afterlives
}

\author{
Dimitris Antoniou, Kostis Kornetis, \\ Anna-Maria Sichani, and Katerina Stefatos
}

A half century after the coup d'état of 21 April 1967, the art exhibition documenta 14 launched its public programs in Athens by revisiting the Colonels' dictatorship. The organizers chose the former headquarters of the infamous military police (EAT/ESA) to host the "exercises of freedom," a series of walking tours, lectures, screenings, and performances that examined resistance, torture, trauma, and displacement in a comparative perspective. The initiative was met with mixed feelings, and its public discussion raised important questions about the past. Why is it urgent today to revisit the junta as a period of acute trauma? Can we trace the roots of Greece's current predicament to its non-democratic past? What remains unsaid and unsayable about the dictatorship and its enduring legacies? ${ }^{2}$

While the junta has been a favorite subject for public history (broadly understood here to include literature, film, personal testimonies, and so on), research on it has remained on the margins. Initially, it was marked by sporadic attempts to respond to the pressing public interest to understand the dictatorship as a contemporary phenomenon (Tsoucalas 1969; Clogg and Yannopoulos 1972; Poulantzas 1976; Mouzelis 1978) and, most importantly, to explain how the Colonels came to power and why they managed to govern Greece for seven years. Subsequently, while historians of Greece started focusing on World War II, the Axis Occupation, and the Greek Civil War, literature on the junta remained fragmented and introspective, never coalescing into a coherent body of work capable of building on collective insights and speaking to broader scholarly debates. Unlike the books of the previous decade, the few scholarly works of the 1980s and 1990s (for example, Alivizatos 1983; Diamandouros 1983; Charalambis 1985; Woodhouse 1985; Bermeo 1995; Meletopoulos 1996; Dafermos 1999; Regos, Athanasatou, and Sepheriades 1999) largely assumed a Greek audience that was both interested in macrohistorical narratives and indifferent to the possibility that the Greek 1960s and 1970s might constitute a 


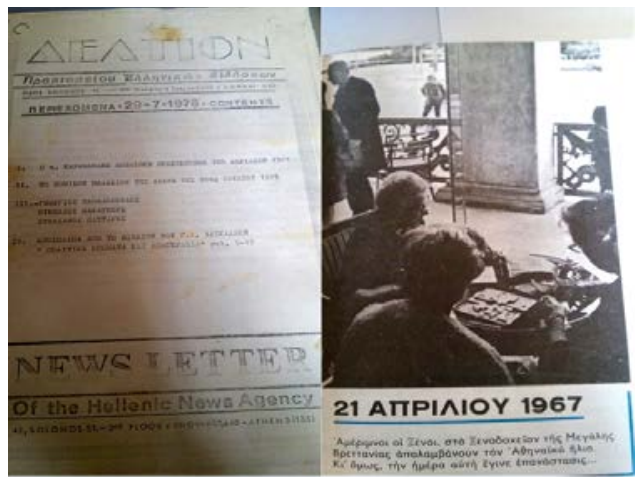

Figure 1. "From the Flea Market," newsletter published by an Anglophone news agency created by the junta's supporters to cover the protaitioi trials (left) and propaganda brochure depicting tourists "enjoying the Athenian sun" on the day of the coup d'état (right). Source: Dimitris Antoniou's personal collection.

productive period from which to consider issues of global and theoretical significance. For the most part, oral history, archival research, and ethnography are largely absent-a telling void if we take into account the great availability of materials in municipalities and cultural and professional associations (not to mention flea markets!), as well as the opportunity that scholars had to engage the former dictators or even lesser junta officials in a comprehensive study of the military regime (Figure 1).

How long does it take for a period to be studied? How simple is it to inquire into the past of a living generation and to document accounts that may depart from canonized narratives? What happens when those who opposed the junta as students become narrators of history? Only recently have scholars begun to address these issues, reflect on the production of history and intergenerational tensions, and consider the period of the junta as a defining moment in recent Greek history and thus crucial to an understanding of the continuities and ruptures with postwar legacies and the entire period from the Metapolitefsi to the present (Van Dyck 1998; Rizas 2002; Papanikolaou 2007; Panourgiá 2009; Walden 2009; Karamanolakis 2010; Van Steen 2010; Stefatos 2012; Kornetis 2013; Nafpliotis 2013; Van Steen 2014; Avgeridis, Gazi, and Kornetis 2015; Papadogiannis 2015; Antoniou 2016; Kallivretakis 2017). ${ }^{3}$

This special section, “The Colonels' Dictatorship and Its Afterlives," builds on this momentum and presents an ongoing conversation among emerging scholars of the period. It draws on research initially presented at a workshop under the same title organized by Columbia University's Program in Hellenic Studies in April 2015. The workshop took as a point of departure the regime's emblem, the phoenix, the magical bird that sets itself on fire only to reemerge from its ashes, to ask how the regime imagined its afterlife and its place in 
history. How does it live on in archives, on film, and in the narratives of those who experienced it, as well as in the imagination of those with no memories of their own?

Clearly a special section cannot hope to deal exhaustively with all facets of the military regime. The articles featured here examine widespread assumptions about the junta and its reception in Greece and abroad, making use of theoretical insights and methodological contributions on dictatorial legacies, while broadening the field of inquiry to comparative analysis and transnational discussion. They also contribute to the broader study of afterlives, along the lines proposed by Kristin Ross in her seminal May'68 and Its Afterlives (2002), in three key ways. First, they point to the mechanisms through which states and societies periodize history and thus mark the boundary between life and afterlife. Second, they challenge this boundary by drawing out the considerable activity that goes into constructing afterlives within lives and by showing how history and memory play crucially with the indeterminacy of this divide. Third, they emphasize the role of certainties and assumptions regarding the historical record in shaping how afterlives emerge, endure, and become productive. The seven articles examine the historical moments, spectacles, and state rituals that marked the transition to democracy (Howe Haralambous), the concepts used in the Metapolitefsi to facilitate its remembrance (Kourniakti), the regime's ideology and mnemonic politics (Kouki and Antoniou), its attempts to emerge as a modernizing force (Samarinis; Nikolakakis), its international reception (Dimirouli), and cultural production at the intersection of musical experimentation and political contestation (Kallimopoulou and Kornetis).

In the following three sections, we consider the afterlife of the Colonels' dictatorship at three different levels. Dimitris Antoniou discusses the analytics of the junta and the way in which particular concepts frame historical inquiry and ultimately shape our understanding of the past. Kostis Kornetis and Katerina Stefatos look at the place of torture in the contemporary memory of the junta. Finally, Anna-Maria Sichani considers anniversaries and the politics of commemoration. 
The junta through the lens of World War II

Dimitris Antoniou

How do prevailing concepts shape understandings of dictatorial pasts? Even a cursory review of scholarship on the junta reveals the central place that concepts such as kitsch, fascism, resistance, and trauma occupy. Instead of taking these concepts at face value and asking, for instance, whether the Colonels really had poor taste, this special section considers how these concepts emerge, get deployed, shape frameworks of inquiry, and render certain questions seemingly unnecessary. Placing emphasis on the history and circulation of ideas, I contend, helps us understand how the junta-right from the start-was received as a replay of a past that involved "Nazi collaborators," "communist bandits," "resistance fighters," and "fascists," and that nowadays lives on also as an afterlife of the World War II and the subsequent civil war. But how exactly do concepts invoke the past and which aspects of the past do they silence?

Let us start with kitsch, a concept that became popular in Greece in the mid-1980s as a result of the systematic effort of the magazine Avii (Anti) to

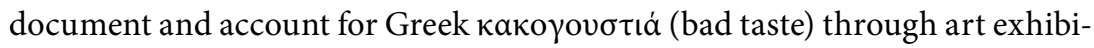
tions and state-sponsored publications (Panagiotopoulos 2010; Antoniou 2016; Kourniakti in this issue). In that context, kitsch was used to discuss the junta's aesthetics - an analysis that could not have been more timely and success-

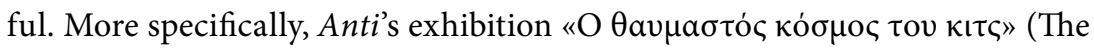
wondrous world of kitsch) in 1984 perfectly coincided with the publication of Milan Kundera's The Unbearable Lightness of Being (1984), which also spoke of kitsch, and, most importantly, with Nikos Perakis's film $\Lambda$ ov $\varphi \alpha \kappa \alpha \iota \pi \alpha \rho \alpha \lambda \lambda \alpha \gamma \dot{\eta}$ (Loafing and camouflage, 1984), a hilarious depiction of military service under the Colonels and dictatorial grotesque, and indeed a smashing success at the Greek box office. Since then the concept has been present in almost every single anniversary article of the mainstream press, as well as in most documentaries about the period (for example, Theologidou 1997; Nerantzis 2 004; A gathos 2010; Lambrinos 2011). At this point, a crucial question emerges: why was the intelligentsia of the 1980s, as represented in Anti's projects by Melina Mercouri, Vassilis Vassilikos, Konstantinos Tsoucalas, and Dimitris Raftopoulos, so eager to speak of kitsch?

I propose two possible answers. Kitsch allowed the junta's opponents to politicize its aesthetics by comparing it to totalitarian regimes of interwar Europe. In Anti's seminal publication Kitsch Made in Greece, for example, Raftopoulos (1989) d raws on Clement Greenberg (1939) to claim that totalitarian regimes such as those of Metaxas, Mussolini, and Hitler used kitsch 
to control the people. By way of a transitive logic (that is, if fascists are kitsch, and the Colonels are also kitsch, then the Colonels are surely fascists), the art critic unmasked the Colonels' ideology and thus further contributed to their regime's delegitimization. Yet kitsch played another crucial role. It facilitated an abjective analysis of "this part of the self that is most clearly ours and yet most undesirable" (Kristeva 1982), of all those Greeks, that is, who brought to power Andreas Papandreou's Panhellenic Socialist Movement (PASOK), but whose aesthetics were as unfortunate as those of the Colonels. As the recent exhibition "Greece in the Eighties" showcased, o גaó (the people) at the time enjoyed karate films, consumed the yellow p ress, and d ecorated their n ew TV sets with doilies. An aesthetic disaster on all fronts! How was that possible for democratic citizens? Kitsch again provided a simple answer: Greece's dictatorial past had resulted in the degeneration of folk aesthetics.

Adopting the lens of kitsch for the analysis of the Colonels' junta, however, had a tremendous impact on public and professional history of the period. On the one hand, it became increasingly difficult to ask whether Greeks had bad taste before the junta (Antoniou 2016; Kourniakti in this issue), and on the other, the concept's inherent emphasis on ridicule and the grotesque overshadowed the more sinister aspects of the regime. In the words of Kourniakti in this special issue, kitsch by the 2000s had also become a "light" way to remember the junta and effectively to forget the systematic persecution of its dissidents.

The connection between the junta and the troubling 1940s was also facilitated through its designation as fascist. This issue shows how from the very moment of its occurrence key dissident publications compared the junta to Metaxas's regime (1936-1941) - already considered fascist by the left-or used the notion of neofascism to emphasize American imperialism, parastate activity, and the workings of a local economic oligarchy. In the context of the antidictatorial struggle, calling the coup of 21 April fascist was not only a means of understanding the political processes that brought the Colonels to power; it was also an effective way to appeal to the world (see Kouki and Antoniou in this issue for Hannah Arendt's response to the Greek putsch), subvert strategic analyses that viewed the junta as a stronghold against Soviet expansion, and demonstrate that the Colonels stood against everything for which the Allies had fought. Necessary as this approach might have been at the time, thinking of 21 April as a straightforwardly fascist regime nowadays creates a rigid framework of historical inquiry. In fact, it prevents us from studying the regime as an ideological patchwork and a work in progress marked by internal antagonisms and constant power struggles. While it is well documented, for example, that Colonel Ioannis Ladas had fascist leanings (to say the least), Georgios 
Papadopoulos, who eventually emerged as leader of the junta, viewed himself as an ideological descendant of prime minister Eleftherios Venizelos (Kouki and Antoniou as well as Howe Haralambous in this issue), the liberal statesman who modernized Greek political life at the beginning of the twentieth century. If we embrace the belief that the junta was an ideologically coherent regime that unanimously adhered to fascism, then the erection of Venizelos's statue in central Athens in 1969 appears as a complete paradox.

Two more concepts feature prominently in the analytics of the junta: trauma and resistance. These too invoke the memory of World War II either in terms of their theoretical or historical origins. Our understanding of trauma as a psychic condition that evades consciousness and expression is largely rooted in theoretical investigations of the Holocaust, an unimaginable elimination of

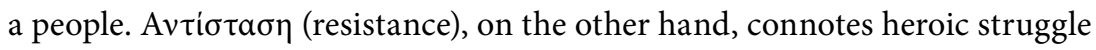
against the occupation forces and their collaborators. While both of these concepts have been employed to describe historical actualities, they also manage to create blank spots in public memory. In her article on the junta's trials, Howe Haralambous describes how the notion of trauma was used strategically on the part of the state to create a comfortable lethe, a calculated forgetting that keeps us safe from the ghosts of our past. In the trials that followed the restoration of democracy, the torturers were eventually viewed as being themselves the subjects of acute trauma-human machines that had lost all agency in the process of their training. A prerequisite for democratic transition was that only the Colonels should atone for the dictatorial past-not formerly common people transformed into torturers. At that time and in the context of the trial of the Colonels themselves, Konstantinos Mitsotakis, thinking perhaps of his future political career, proposed passive resistance as Greek society's primary stance towards a regime that voluntarily passed on its power to Karamanlis (Howe Haralambous in this issue). Like many others, he laid the foundations for a powerful historical narrative that portrayed the people as rightful, even though less dynamic, heirs of the combative spirit of World War II.

Recent research on tourism, urban planning, and technocratic expertise, however, points to aspects of the dictatorial past that evade analysis along the lines of trauma and resistance. Both Nikolakakis and Samarinis in this issue, for example, show how a dictatorship becomes naturalized through the implementation and presentation of particular developmental and modernization policies. Indeed, up until the oil crisis of 1973, the tourism industry and the construction sector were expanding, and Greece was emerging as a popular destination for tourists who blatantly disregarded the boycott campaigns of the 
antidictatorial struggle. To extend Justin Crumbaugh's (2010) insights on tour-ism in Spain under Franco to the Greek case, these dynamics of development as expressed in the tourist industry and in popular filmic discourse predisposed parts of the population to embrace the Colonels' discourse that Greece was experiencing an economic revival. Furthermore these dynamics were sustained by the professional activity and research of individuals who did not necessar-ily embrace the junta's politics. In a rather telling example that highlights the rigidity of the concepts of resistance and its counterpart, complicity, Samarinis refers to the Law 1003/71 "On Active Urban Planning and Organized Build-ing," which was introduced by the regime in 1971 while the person behind it, Kostas Sofoulis, was in political exile. After the restoration of democracy, the law reflecting Sofoulis' visions was considered $\chi 0 u v \tau \iota k o ́ \varsigma$ (of the junta) by architects and their professional

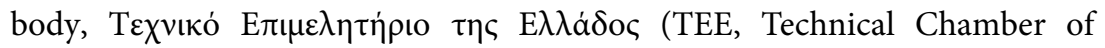
Greece), which conducted systematic research to identify "the junta's collaborators." In this case, what is collaboration? What is complicity? What is trauma?

The study of World War II and the subsequent civil war in Greece shapes contemporary research on the Colonels' regime in yet another important way. Vehement debate in Greek academia over violence, collaboration, and his-torical revisionism has perhaps instilled apprehension in emerging scholars that any new research suggesting the existence of popular support for the junta might be taken as the scholar's endorsement of the regime and an act of disrespect to those who were tortured and displaced during its seven-year period. Nevertheless, in the careful formulations of new research on the period, in the telling gaps of the bibliography, and in the corridors of conferences and workshops, a foundational certainty of the Metapolitefsi seems to crack: are we really to believe that the regime never enjoyed any kind of popular support? And if so, what happened on the evening of 21 April 1967 to those $\varepsilon \theta v$ vкó $\varphi \rho o-v \varepsilon \varsigma$ (national-minded) Greeks in the era of "weak democracy" (Nikolakopoulos 2001) who were frustrated with contemporary politics? In the absence of vital information about the period, it is, I believe, crucial to revisit the question that Photos Lambrinos posed in

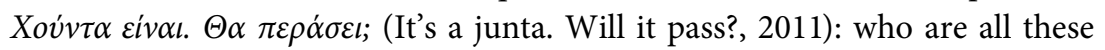
people whom we see in the newsreels applauding the dictators as they visit their towns? 
Greek junta and (female) torture:

From an askesis in forgetting to an askesis in remembrance?

Kostis Kornetis and Katerina Stefatos

Contrary to common perceptions, the public memory of the Colonels' dictatorship in Greece is fragmented, involving a series of omissions, silences, projections, and overcompensations. Within the hegemonic, postdictatorship political discourse and praxis of democracy, the narrativization of the authoritarian regime became dominated by the heroization of the 1973 Polytechnic uprising. This selective remembrance attempted to "institutionalize" the notion of resistance, active or "passive," while sweeping under the rug the extent of complicity and passive acceptance and obliterating the fact that a substantial part of the Greek populace benefited from the junta (Kornetis 2013, 46; Howe Haralambous in this issue). Moreover, no memory exists on the contested issue of the preservation of the status quo ante of the civil servants, as well as of much of the judiciary, the police, and the armed forces during the transition to democracy. Full purges never materialized, in contrast, for instance, to contemporary Portugal, where the rupture had a much more radical character. Instead, a celebratory narrative of the transitional justice was promoted in Greece post-1974 not only by politicians but also by legal and social science scholars (Alivizatos and Diamandouros 1997). The well-known jurist Nikos Alivizatos in fact recently referred to the trials as a "forgotten achievement" (Alivizatos 2017, 57).

This introductory section addresses the reemerging issues of the memory of the past, the realities of the transition to democracy, and their connection to torture. Focusing on the economic crisis that was set off in 2010 as a generational (post)memory trigger and using the documenta 14 exhibition in Athens in 2017 as a case in point of a compelling afterlife, it highlights the importance of torture for understanding the complexities not only of the Colonels' regime but also of the memory work around this period.

In late 1969, the European Commission on Human Rights took measures to have Greece expelled from the Council of Europe, on the grounds of its systematic use of torture. ${ }^{4}$ The expulsion was also connected to a continuous boycott of Greek tourism by antijunta and human rights activists abroad (for the importance of the tourist industry for the regime of the Colonels, see Nikolakakis's contribution in the current issue). The Greek case stands out, as torturers were put on trial after the collapse of the dictatorship and were not amnestied, as happened after the collapse of authoritarian regimes in Spain, Turkey, and Latin America. Nevertheless, the condemnation of torture by the 
Greek justice system was not as vocal as we tend to believe, and some of the most notorious torturers received surprisingly short sentences. The Trials of the Torturers, as they came to be known, that took place in Athens (Korydallos Prison), Chalkida, and Patras from August to December 1975 were far from exemplary. As the Amnesty International Report on the First Torturers' Trial notes $(1977,63-66,72-78)$, the sentences in most cases were either significantly reduced, suspended, or the accused were acquitted, while a significant number of cases were never brought to justice. In the Chalkida trial (the first security police trial, November 1975), where the accused were high-ranking officials of the Security Police (Asfaleia) and members of the Central In formation Agency (KYP), the victims described a climate of mockery, fear, and intimidation. ${ }^{5}$ As noted by Nantia Valavani, a former junta dissident, only four out of the fourteen policemen accused of acts of torture were sentenced to a few months imprisonment, revealing the instrumental role of the police (and gendarmerie) forces within the democratic establishment of the postdictatorial state (Amnesty International 1977, 63; Valavani 2005; Kampilis 2009; Stefatos $2016,30)$. Despite the vivid interest of a part of the conservative political establishment in the trial (Paschaloudi 2017, 127), during the judicial process a close collaboration was revealed between the postjunta transitional regime of New Democracy and police forces that were on trial, as Howe Haralambous discusses in her contribution to this special section.

Concurrently, an "askesis in forgetting” (Panourgiá 2009, 150-151) was put into effect. A repression of the traumatic lived experiences of violence, sexual torture, and incarceration of hundreds of men and, especially, women ran parallel to the obliteration of popular complicity and the idolization of the Polytechnic. A regime of silence was adopted, not necessarily or not always imposed from above, but often s elf-imposed out of g rief, shame, a nd fear of trauma transmission. ${ }^{6}$ Targeting women's political identities, sexuality, and concepts of motherhood and maternity proved to be of paramount importance to the coercive regime, while promiscuity and subversion were inextricably linked to its nationalistic and religious propaganda. In reference to the politicized motherhood of Argentina's Mothers of Plaza de Mayo, Diana Taylor analyzes the Virgin Mary image of purity, submissiveness, and ("compulsory") motherhood alongside the virgin/whore dichotomy of the politically incorrigible women dissidents (Taylor 1997, 83-86, 195-196; see also Franco 1984). ${ }^{7}$ This portrayal of women dissidents as impure and subversive was prevalent during the torture and internment, but also in the official discourse that legitimatized the torture. The political detainees very often attempted to downgrade their sexual victimization or to situate their traumatization within the context of their political 
activism. Although their reticence and inability to turn their traumas into discourse against female dissidents during interrogation and internment turned into the epitome of biopolitical existence, within a necropolitical experiment of sorts (Mbembe 2003; Franco 2013, 4-5), the torturers staunchly denied that they had tortured women (Haritos-Fatouros 2003, 59, 82).

In addition, there is hardly any public memory of the trials themselves at present. And this is all the more surprising if one takes into account the fact that torture was one of the most powerful popular references when the regime fell. Three gigantic concerts that took place at Panathinaikos stadium with composer Yannis Markopoulos and two at Karaiskaki stadium with Mikis Theodorakis in September and October 1974, respectively-immortalized in

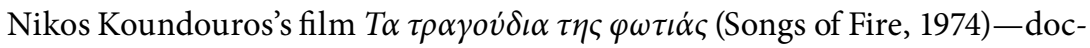
ument this fact. One of the standard slogans shouted by the spectators was «E $\Sigma \mathrm{A}, \mathrm{E} \varsigma \mathrm{E} \varsigma, \beta a \sigma \alpha v i \sigma \tau \dot{\varepsilon} \varsigma »$ (ESA, SS, Torturers)-a reference to the notorious

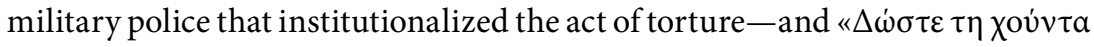
$\sigma \tau$ خaó» (Give the junta to the people), referring to the popular demand for

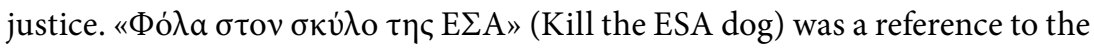
so called invisible dictator, Dimitrios Ioannidis, who had been the notorious Head of the ESA prior to his involvement in the coup d'état against Makarios in Cyprus. One of the most emotional moments during the concerts was when well-known singer Antonis Kalogiannis sang Mikis Theodorakis's « $\Sigma \varphi \alpha \gamma \varepsilon i o »$ (Slaughterhouse), a song with direct references to torture (Papadogiannis 2015, 87). The film captures people's reconquering of the hitherto deprived public sphere with a symbolic passage from silence to sound-a passage that had already started not only in open spaces, such as the Law School terrace or the yard of the Athens Polytechnic in 1973, but in closed ones, too, like the music club Kyttaro. The latter featured some of the same artists who performed in the stadiums and prefigured the synesthetic elements that came to dominate the scene in the concerts of 1974 which marked the Metapolitefsi (see in this respect Kallimopoulou and Kornetis' contribution in this issue).

With the exception of the period from the collapse of the junta in the summer of 1974 up to the late 1980s, during which this intense public interest in the subject matter of torture was recorded, ${ }^{8}$ there followed a period of indifference towards the topic, in line with the gradual depoliticization of the 1990s. The Greek case is not unique in the ways in which tragic events and the lived experiences of the subaltern, the defeated, and the silenced are excluded from acts of public remembrance, of collective memory, and of the official construction of history; we need to underline, nevertheless, the absence in Greece of a discourse on collective trauma, especially in relation to the junta period, barring 
the aftereffects of trauma from being in corporated in to a "m emory archive" (Huyssen 2003, 6; cited in Hirsch 2012, 3). The materiality of sexual violence, of torture, and of terror, as well as the suffering and traumas themselves have not been made tellable or knowable, nor have they been narrativized within an official discourse of history, preventing their integration into "collective consciousness" (Neal 1998; cited in Pickering and Keightley 2009, 6; Stefatos 2016b).

Crisis as a memory trigger. A renewed interest in the junta began with the onset of the economic crisis in 2010 that put in doubt some of the fundamental premises of the country's transition to democracy. The period of the Colonels' rule itself became a point of reference in the summer of 2011, when a grassroots social movement emerged in Greece, rallying against the austerity measures adopted by the government. Their slogan-"Bread, education, freedom. The junta did not end in 1973"- brought the past to the fore by adopting the most famous catchphrase of the Polytechnic student uprising, implying continuity in terms of the Greek state's brutal tactics in spite of the transition to democracy. While a third generation rediscovered the painful past and instrumentalized it, consciously using the memories of those detained and tortured to fight against both amnesia and repressive policies of the twenty-first century, former junta detainees themselves seemed to agree with this kind of reading. A useful theoretical tool here is that of postmemory, a term reflecting the uneasy oscillation between continuity and rupture around trauma in intergenerational

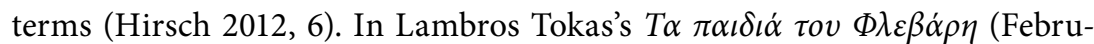
ary's children, 2014), a volume on personal testimonies of junta dissidents and political detainees, the latter seem to share to a large extent the view that even though the violation of human rights during the military dictatorship cannot be compared to that of a liberal democracy, there are some similarities and troubling continuities, especially within the context of socioeconomic crisis, neoliberalism, and globalization.

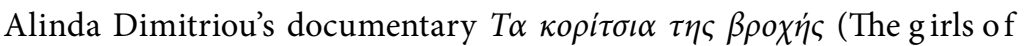
the rain; 2011) makes a similar point regarding the current state of affairs in Greece. Right in the midst of the crisis, Dimitriou interviewed 50 women who had been tortured during the long 1960s in Greece. This sociopolitical reemergence of past activists in the public sphere reminiscent of Barbara Sutton's (2007) reference to Argentina's own financial crisis as "poner el cuerpo," namely, the act of (women) putting their (political) bodies in a line, but also of women around the so-called Arab Spring and the Gezi Park protests in Turkey. ${ }^{9}$ These women legitimize their political involvement by politicizing traditional feminine tropes, by queering and disrupting the public space, while 
also drawing a continuity with their past struggles, where the dehumanized and abused body of female prisoners resisted by holding on to their political identities and subjectivities. ${ }^{10}$ This is part of an attempt to shatter state narratives and official discourses, materialized during torture, persecution, and imprisonment. After some of her interviewees recounted the ways in which they were brutally tortured, Dimitriou makes jump cuts to images of present-day police brutality, mostly during clashes with protesters at Syntagma Square. By arguing that the repressive mechanism of the Greek state has not been democratized and that a hardline antidemocratic structure has remained intact, she makes a powerful, albeit controversial, ${ }^{11}$ statement regarding the supposed continuity of authoritarianism (Kornetis 2014a).

The period since the onset of the economic crisis witnessed an intense artistic interest in the topic of torture, depicted in novels, graphic novels, films, and documentaries, as well as in autobiographical writings. An interesting case was an installation by musicologist Anna Papaeti and sound expert Nektarios Pappas in 2016, within the framework of the much acclaimed $\Upsilon \Pi$ חO $\Sigma$ Project. Excerpts from the 1975 Trials of the Torturers and audio interviews revealed the widespread use of radio and popular songs during detention and interrogation, played in a loop day and night, in conditions of total isolation, as an effective torture technique that would lead to sleep deprivation and psychological collapse. The installation involved an empty cubicle that was reminiscent of a cell, whereby a terrifying sensory experience included a trembling dim light and the sounds of iron bars, intermingled with bell rings and distorted songs. This multisensorial experience was true to the original form of torture itself, but it also made one reflect on the devastating effects of this sonoric bombardment under detention (a form of torture still widely used). ${ }^{12}$ As Papaeti herself

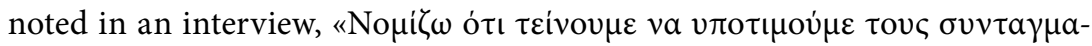

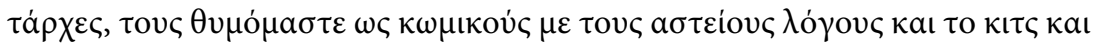

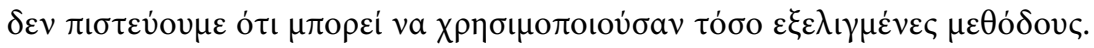

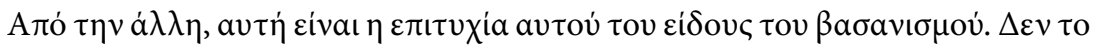

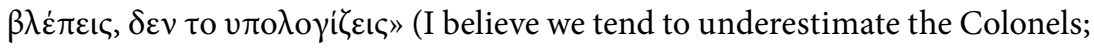
we remember them through their funny speeches and their kitsch, and we don't think of them as capable of exercising such developed forms of torture. But on the other hand that is precisely the power of this kind of torture. You don't see it, you don't expect it; Papaeti 2013; see also Ioannidis 2016.).

Indeed, the hegemonic portrayal of the junta-in stark contrast to the idea of the continuation of its brutal tactics by other means-privileges its comical side, the grotesqueness of the dictators, and the ridiculous aspects of the regime. By understating the seriousness of everyday repression and 
overstating the vulgarity of the regime, a picturesque image had been created, reducing the Colonels to cardboard characters of a kitschy and light culture which was highly trivializing (see contribution by Kourniakti in this issue). Drawing on Roger Silverstone's notion of "proper distance" (2007), media specialist Marita Sturken has argued that trivialization, irony, domestication, and kitschification can be used as a mediating device to create modes of both distancing and proximity in order to rationalize torture and atrocities, through a sense of familiarity, and perhaps an illusion of empathy (Sturken 2011, 2). Thus, the caricatured dictatorial figures are denied agency and are rendered incapable of performing torture or instigating a brutal, authoritative regime. In reality, however, the junta persecuted, censored, manipulated, repressed, and ultimately tortured in a systematic and methodical way, creating a heritage from which we are still not entirely liberated (Kornetis 2014b, 97).

Document-ing horror. In September 2016, the former Special Interrogation Unit/Greek Military Police (EAT/ESA) (currently the Museum of Antidictatorial and Democratic Resistance/Parko Eleftherias) became the epicenter of documenta 14, the radical quinquennial German exhibition. The location was previously one of the main sites of detention, interrogation, and torture of political activists and suspected citizens during the junta-a fact that was not lost on the Polish and Spanish curators of the exhibition, who chose the specific site precisely for its dark past, as well as its spatial and political symbolic power, in an attempt to render Greece's traumatic history of political violence and state terror visible, relevant, and comparable to similar oppressive regimes in Latin America (Chile, Argentina, Guatemala, Brazil). Through this exhibition, the curators chose to stress the connections between the end of the dictatorships in the global South in the 1970s and 1980s and the emergence of neoliberalism, a controversial decision according to parts of the Greek press. The responses on behalf of much of the center-right and center-left press alike were polemic, to say the least. ${ }^{13}$ Involved in this criticism was writer Elias Maglinis, who had

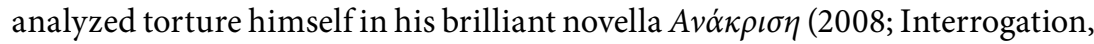
2013), which tackled the intergenerational trauma transmission between a father who had been tortured at the EAT/ESA headquarters in the past and his artist daughter in the present. Maglinis, not unlike other commentators, accused the conveners of the exhibition of having little knowledge of the fact that Greece did not go through the neoliberal turn of, say, Chile after 1973, hence rejecting the title "From Dictatorship to Neoliberalism," used by the curators in their opening manifesto, as entirely misplaced (Maglinis 2016), while others deemed the revival of the past as politically suspicious. 


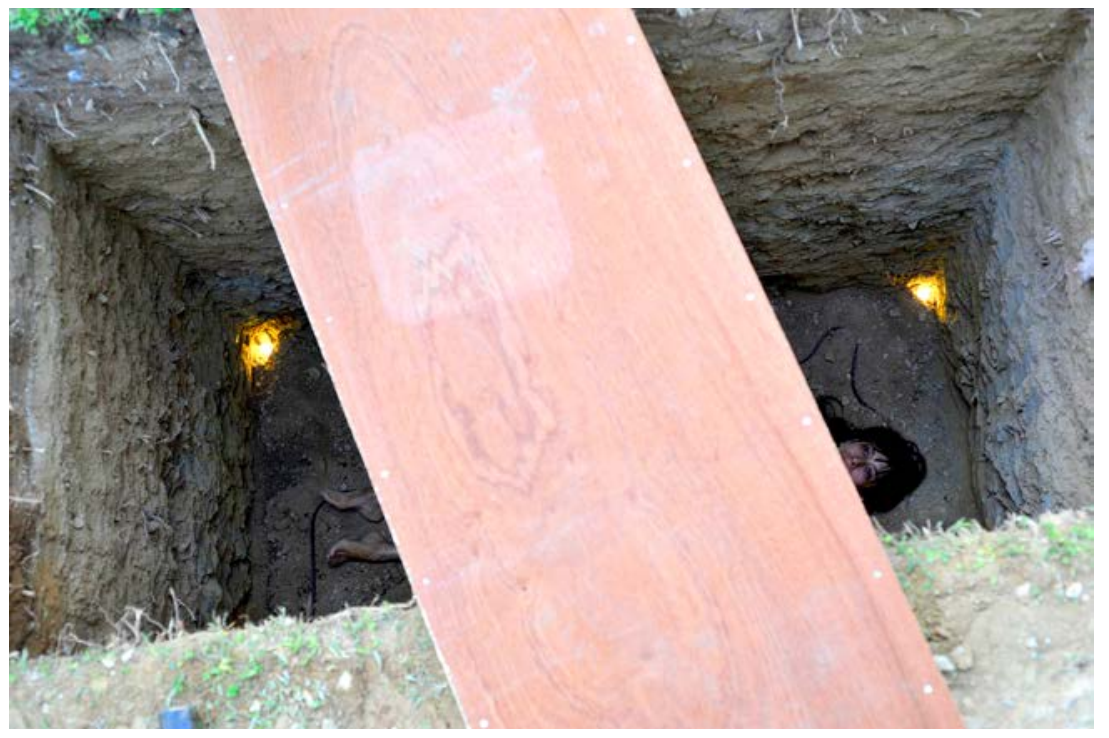

Figure 2. Regina José Galindo, “Ojo de gusano: Don’t Look Down,” performance, 2016. Source: Courtesy of documenta 14. Photo: Stathis Mamalakis.

One of the most anticipated performances within documenta 14 that dealt directly with the commonalities and trajectories among different dictatorial regimes in their brutal practices that instrumentalized the body was that of the renowned Guatemalan performance artist and poet Regina José Galindo. In her performance, entitled “Ojo de gusano: Don’t Look Down” (Figure 2). Galindo returns to the omnipresent subject of the fetishization and sexualization of the female body by the state and the media during incarceration and torture. In her performances, the audience or the bystander becomes complicit through social amnesia and apathy in the terror, torture, gender violence, and impunity performed or justified by state and paramilitary apparatuses, religious leadership, or the media. ${ }^{14}$ The audience waits patiently in line, a few feet away from the buildings of the Military Police and its Interrogation Unit, where hundreds of dissidents were dehumanized and systematically tortured, while Galindo lies naked with her eyes open, in a makeshift, open, lightly lit grave, a wood board placed diagonally on top of it; one by one, members of the audience are invited to walk towards the grave, to stare down at it and at Galindo's naked body. Some seem timid, avoid staring directly at the artist's naked body, while others kneel towards the grave, step on the board, and spend more time on the performance site. In a way, Galindo's performance takes the form of a religious experience in which the members of the audience, one by one, not en masse, pay 
their respects to the dead or to a sacred figure, lying in its final place of rest, a ritual that in the context of the Greek Orthodox tradition is familiar through both martyrdom and the mourning of loved ones.

Documenta 14 attempted to render the political, subaltern bodies of women (alongside those of immigrants and transgender individuals) visible, reintroducing through this comparative perspective the Greek military dictatorship as a contested subject. Regardless of the media coverage of the event and the invocation of a historiographic misstep, it was the instrumentality of the body, in its physicality and performative power, that formed the core of documenta 14's creative practice. It also proved to be an anchor point for direct connections to continuities and discontinuities of the traumatic, authoritative past of the junta in relation to torture, political terrorization, and sexual abuse. The political and performative body of political activists and junta dissidents-sexualized and desexualized, politicized and depoliticized by means of detention, as well as incarceration, dehumanization, and torture-prevailed in the talks and performances of documenta 14, always in connection to the current crisis.

Similar cases can be seen in Spain, Portugal, and Argentina, whereby one can observe a need for rediscovering the past in the context of economic crisis, past injustices, and the recovery of "historical memory." A great difference with the case of Greece is the absence of organized demands of accountability regarding the dictatorship period, most notably from local human rights groups and transnational advocacy networks. Such voices are very much present in Spain, Argentina, Chile, and Guatemala. The absence in Greece may reflect the longer $d$ uration and $g$ reater d uress of those respective r egimes, compared to the Colonels, but also the different $n$ ature of the transitional processes and justice systems. However, even though in Greece there are no persistent actors and militants who continue to fight for their memories (like human rights groups, journalists, and judges), there is nevertheless a context of growing civic engagement, a public "still implicated in each other's trauma" (Caruth 1996, 18, 24), and a history which is not fixed but constantly shifting. As Galindo's performance showcased, there are similarities in the ways in which the fetishized, abused fe/male bodies of political activists and prisoners were rendered visible and sacred (Agamben 1998), almost Christ-like sacrificial symbols, in as diverse contexts as Chile and Argentina, or with indigenous Guatemalan women and young female workers at the maquiladoras in Ciudad Juarez, but also in Greece. Galindo reappropriated the fe/male bodies and bodily habitus (Bourdieu 1977; cited in Cerullo and Valiño 2014, 93) of the dissidents who were once deemed unworthy and promiscuous, turning them 
into living mnemonic sites and resistive texts against the backdrop of official silence and social amnesia.

The present special section touches upon such issues, especially through the contributions by Howe Haralambous and Kourniakti, without entering in depth into the politics of representation. However, the centrality of repressed memory, trauma, postmemory, performativity, and the private versus public aspect, and of the comic versus brutal side of the Greek regime cries out for more scholarly attention to the seven-year dictatorship and its legacies and afterlives-not in isolation but in comparison with other authoritarian regimes, at least in terms of the bodily experience and the gendered aspect of torture. Fifty years since the imposition of the military dictatorship, more "askesis in remembrance" is in order, so that the taboos of recent history can be decisively dealt with head on.

The junta's afterlives and the present pasts

Anna-Maria Sichani

This year's $50^{\text {th }}$ anniversary of the 21 April 1967 coup and the imposition of the military junta in Greece serves as a point of critical reflection on the interplay between the historical past and our present, as well as on the politics of collective memory, public history, and academic historiography. Anniversaries in general generate an elusive tension between the then and the now, as remembrance, discussion, and debate persistently bring the past into the present. Anniversaries of historical events are by definition used as markers of historical time, while instating memory as a social and cultural rather than as a purely individual activity (Halbwachs 1952; Connerton 1989; Samuel 1996). Moreover, the very choice of the date of the anniversary alongside the commemorations could be seen as processes of memory formation. Depending on the nature of the commemorated event, the practices and discourses surrounding the past might become a celebration, a moment of mourning, a point of conflict, or even an occasion for reassessment.

The nature and evolution of anniversaries and commemorative endeavors following the Greek military junta over the past 50 years offer a telling example of the social formation of memory as a dynamic procedure. In 1981, the newly-elected PASOK government proposed and established 17 November as a statutory holiday, commemorating the 1973 Polytechnic student uprising 
and reaffirming a ma ss public de mocratic consensus ag ainst the Colonels' authoritarian regime. Though likely a premature attempt to institutionalize and thus to historicize an event and a broader period of the raw past, it assisted in establishing, both on an institutional level and in public memory practices, a consolidated myth of the Polytechnic alongside other narratives of political and ideological resistance to the regime. For its protagonists, remembering and discussing the junta period in the public sphere of the 1970s, 1980s, 1990 s, and early 2000s became a highly political instrument for legitimization, foregrounding their popular associations with resistance and democracy.

However, exalting the Polytechnic uprising both as the epitome of a seven-year period and as a universal reaction to the Colonels' regime has also facilitated a collective forgetting of the junta period in its entirety-namely, of the passive consent to the Colonels' regime demonstrated by a considerable portion of the Greek population. Commemorative practices surrounding the Polytechnic events have been featured in school celebrations, marches to the US embassy, and anniversary stone-throwing between rioters and the police. These commemorative rituals serve to situate transition, political activism, state repression, and anti-Americanism at the epicenter of public memory of the junta. Given that "it is memory that dictates while history writes" (Nora 1989, 21), by the early 2000s, a "black hole" (Pimplis 2005) had emerged in the historiography of the period. What little scholarly interest was channeled into the period originated mainly from the fields of political science and sociology (Regos, Athanasatou, and Sepheriades 2008), while the few historical studies were limited to autobiographical or journalistic accounts (Kallivretakis 2007).

Since the late 2000s, as a result of the recent Greek socioeconomic crisis, a renewed interest in the junta has emerged. The junta has more than ever been present in public discourse and in everyday practices (beyond the formal anniversary dates of its arrival and fall). In this revival, however, emphasis has been placed on the Metapolitefsi era, focusing not on the democratic transition per se but mainly on the related Metapolitefsi culture, that is, the supposed corruption, corporatism, and extreme populism of Greek state and society that led to, among other things, the crisis (Avgeridis, Gazi, and Kornetis 2015, 15). On the other hand, discussions of the period of the Colonels' regime have also functioned as a means to address the longue durée as well as the afterlives of the state's repressive policies and violence. In 2011, "Bread, education, freedom. The junta did not end in 1973" featured as an emblematic slogan of the Greek grassroots social movement, referring to the government's austerity measures; in the summer of 2015, the popular Twitter hashtag \#thisisacoup trended after the Syriza government's signing of the Third Memorandum, articulating a 
proclamation against the financial and undemocratic political interventions of the European Central Bank and the European Union in Greek politics. At the same time, the age of fear heralded by the refugee crisis, the growth of nationalism and of the extreme right, the fear of terrorism, and international conflicts have brought the politics of otherness and the precariousness of the human body to the forefront of public discourse, all of which is proof that even today the basic values of democracy, justice, human rights-values that the junta brutally infringed-are still often at stake.

Not surprisingly, as we distance ourselves chronologically from the junta and critically from its resistance narratives, opening inquests into its less heroic legacies, we have embarked on original scholarly research that sheds light on the diverse and previously neglected social, cultural, economic, and ideological aspects of the period (see, for example, Van Dyck 1998; Papanikolaou 2007; Van Steen 2010; Van Steen 2014), as well as of the regime itself (in this respect, see in this issue Nikolakakis's and Samarinis's contributions on the regime's policies). In a similar vein, we have also been able to venture comparative examinations and historical accounts of aspects of Greek society that further challenge notions of rupture and continuity within which the junta was traditionally debated (Kornetis 2013; see also the contributions of Kourniakti on the kitsch perception, Kouki and Antoniou on the relationship of the Colonels' junta to Metaxas' regime, and Kornetis and Kallimopoulou in this issue). Assisting our endeavors, more and more archival material has gradually become accessible for research; more importantly, an ever increasing amount of material traces of the junta's past are becoming "archival." Here I am using the Derridian notion of the "archive," by referring to the toponomological notion of the term, describing the process of accumulating material assets in a physical space and assigning upon these a "hermeneutic authority" (Derrida 1995, 10). By this, I mean, for example, that the detention centers of EAT/ESA or Bouboulinas have always been there as formal historical sites; but it was only over the course of the past year's documenta 14 events that a vast public engagement with them was attempted, turning them into lieux de mémoire, capable of generating affective recollections "by nature multiple and yet specific; collective, plural, and yet individual” (Nora 1989, 8).

The present as a set of experiences and as a "regime of historicity" (Hartog 2016) thus becomes an important variable for assessing and revisiting the junta's past, in terms of both public and academic history. In the current "regime of presentism," the "sense of a permanent, elusive and almost immobile present, which nevertheless attempts to create its own historical time" (Hartog 2016, 17-18), further blurs the ways of articulating boundaries and 
relationships among past, present, and future. To this end, this year's anniversary not only marks a fresh, challenging, and heterogeneous engagement with the junta period; it also serves as a critical reflection on the accumulation and the conflict of the different memory waves and historical narratives around the dictatorship over the last 50 years. Opening up again the discussion on the junta begs for a timely account of the ways in which and reasons for which we have been dealing with this case for the past five decades: collective memory has its history, too.

\section{NOTES}

Acknowledgements. We would like to thank Artemis Leontis, Thomas Gallant, Nick Geller, and the anonymous reviewers for helping us prepare the manuscripts for publication and for their careful readings and clear advice, as well as Antreas Oikonomopoulos for his technical assistance. Karen Van Dyck and Mark Mazower embraced the workshop “The Colonels' Dictatorship and Its Afterlives" right from the start and made sure that it took place as we imagined it at Columbia in April 2015. Neni Panourgiá was the first to propose the idea for a special issue of the JMGS, and, as always, she has been a dedicated friend and an unending source of enthusiasm and support. Lastly, we would like to thank all workshop presenters, discussants, and participants for their contributions.

${ }^{1}$ The title of one of the exhibition's public programs was "34 Exercises of Freedom" (http:// www.documenta14.de/en/public-programs/928/34-exercises-of-freedom).

${ }^{2}$ Nine months later, in the aftermath of an academic conference, an article by political scientist Stathis Kalyvas in Kathimerini (2017) on the afterlives of the junta-which he compared to an old furniture that one is used to seeing in one's house, but whose existence one ends up neglecting-generated heated exchanges in the press on the nature of the regime and the memory thereof at present. Kalyvas's lack of references to violence, his view that the 1967 coup accelerated to a degree the democratization that came after the regime's collapse in 1974, and in particular his conclusion that the latter constituted an "interval" that was overcome swiftly and easily by Greek society instigated polemic responses and bitter critiques. For example, see Doxiadis 2017, Kanellopoulos 2017, Kornetis 2017, Mavrogordatos 2017, Samantas 2017, and Mandravelis 2017.

${ }^{3}$ For an overview of the recent scholarly production on the military junta and the bibliographic gaps in relation to the period, see Kallivretakis 2007; Karamanolakis 2010; Skordos 2010; Kakouriotis 2016; Tsakas 2017.

${ }^{4}$ See in this respect Becket 1970; Konstas 1976; Yiourgos, Kampilis, and Becket 2009.

${ }^{5}$ Also see the Amnesty International Report on the First Torturers' Trial 1975 (1977, 63-65); Valavani 2005; Kampilis 2009.

${ }^{6}$ Historian Vangelis Karamanolakis (2009) makes a similar argument in relation to the civil war traumas, personal and collective, and emphasizes the fear of recalling a past that was connected to death, violence, defeat, and humiliation. 
${ }^{7}$ Also see Marguerite Feitlowitz's seminal A Lexicon of Terror ([1998] 2011, 56-60, 76-77).

${ }^{8}$ Indicatively, see Starakis 1974; Arseni 1975; Daraki-Mallet 1976; Korovesis 1983; HaritosFatouros 2003.

${ }^{9}$ For instance, the Madres and Abuelas de la Plaza de Mayo (Mothers and grandmothers of the Plaza de Mayo; Taylor 1997, 186-189); queer and female bodies in Gezi Park (Zengin 2013; Acar and Ulug 2014), gendering the Arab Spring (Pratt 2013).

${ }^{10}$ Cerullo and Valiño 2014; see also Arseni 1975 and Feitlowitz (1998) 2011, as well as the memoirs by Alicia Partnoy (1998) and Aspasia Karra's testimony (2006).

${ }^{11}$ It is important to note here that some of the interviewees felt uncomfortable with Dimitriou's choice to juxtapose torture in the 1970s with police brutality in the 2010s.

${ }^{12}$ What Sturken describes as the "unspeakable scenarios" $(2011,7)$ in reference to the torture perpetuated by the US in Guantanamo and Abu Ghraib.

${ }^{13}$ For example, see Adamopoulou and Falida 2016; Astrapellou 2016; Pournara 2016. On more reactions in English regarding the documenta 14 controversy, see Puelo 2017.

${ }^{14}$ See Emilia Barbosa's (2014) insightful analysis of Galindo's work, especially in reference to "279 Golpes" (2005); also see Galindo's performances "The Pain in a Handkerchief" (1999) and "Who Can Erase the Traces" (2003).

\section{REFERENCES CITED}

Acar, Yasemin, and Melis Ulug. 2014. "The Body Politicized: The Visibility of Women at Gezi." Roar Magazine, 9 January. Accessed 10 April 2017. https://roarmag.org/essays/women-gezi -park-protests/.

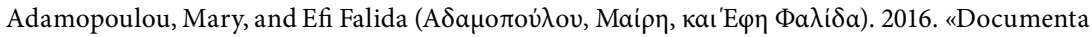

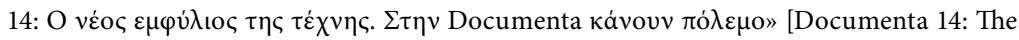
new civil war of art. At Documenta they wage war]. Ta Nea, 17 September.

Agamben, Giorgio. 1998. Homo Sacer: Sovereign Power and Bare Life. Translated by Daniel HellerRoazen. Palo Alto: Stanford University Press.

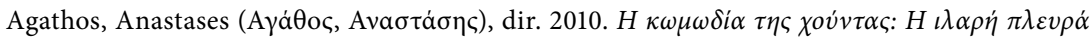
$\mu \iota \alpha \varsigma \sigma \kappa o \tau \varepsilon \iota v \dot{\eta} \varsigma \varepsilon \pi o \chi \eta \dot{~[T h e ~ c o m e d y ~ o f ~ t h e ~ j u n t a: ~ T h e ~ h i l a r i o u s ~ a s p e c t ~ o f ~ a ~ d a r k ~ e r a] . ~ D V D ~}$ accompanying Ta Nea, 17-18 April. Athens: Lambrakis Press Group-Urgh Productions.

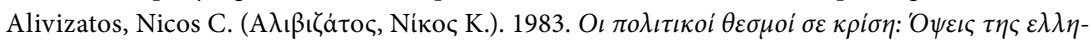

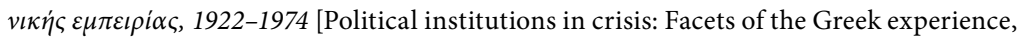
1922-1974]. Athens: Themelio.

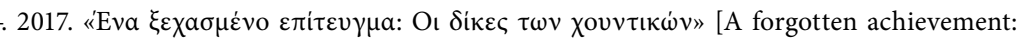

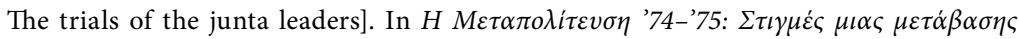
[Metapolitefsi 1974-1975: Moments of a transition], edited by Vangelis Karamanolakis,

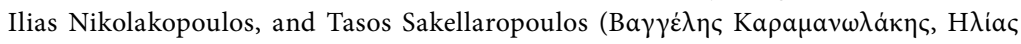

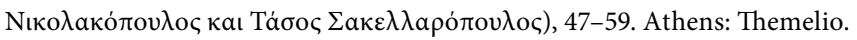

Alivizatos, Nicos C., and Nikiforos P. Diamandouros. 1997. "Politics and the Judiciary in the Greek Transition to Democracy." In Transitional Justice and the Rule of Law in New Democracies, edited by James A. McAdams, 27-60. Notre Dame: University of Notre Dame Press. 
Amnesty International. 1977. Torture in Greece: The First Torturers' Trials. London: Amnesty International.

Antoniou, Dimitris. 2016. “Unthinkable Histories: The Nation's Vow and the Making of the Past in Greece." Journal of Modern Greek Studies 34 (1): 131-160.

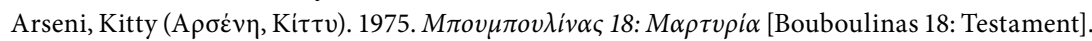
Athens: Themelio.

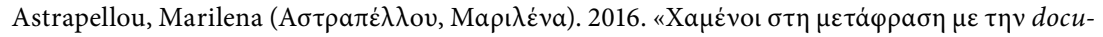
menta» [Lost in translation with documenta]. To Vima, 11 September.

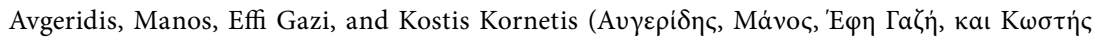

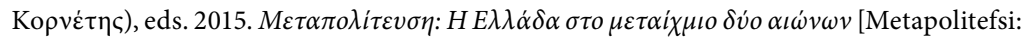
Greece at the threshold of two centuries]. Athens: Themelio.

Barbosa, Emilia. 2014. "Regina José Galindo’s Body Talk: Performing Feminicide and Violence against Women in 279 Golpes." Latin American Perspectives 194 (41.1): 59-71.

Becket, James. 1970. Barbarism in Greece. New York: Walker.

Bermeo, Nancy. 1995. "Classification and Consolidation: Some Lessons from the Greek Dictatorship.” Political Science Quarterly 110 (3): 435-452.

Bourdieu, Pierre. 1977. Outline of a Theory of Practice. Cambridge: Cambridge University Press.

Caruth, Cathy. 1996. Unclaimed Experience: Trauma, Narrative, and History. Baltimore: Johns Hopkins University Press.

Cerullo, Margaret, and Raziel Valiño. 2014. "The Lives of Lupe/Lupin: A Queer Mexican Story in the Time of Neoliberalism." Latin American Perspectives 41 (1): 89-106.

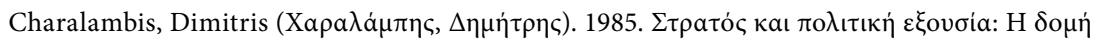

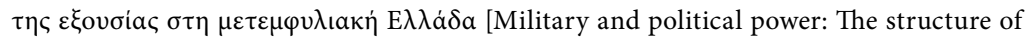
power in post-civil war Greece]. Athens: Exantas.

Clogg, Richard, and George Yannopoulos, eds. 1972. Greece under Military Rule. New York: Basic Books.

Connerton, Paul. 1989. How Societies Remember. Cambridge: Cambridge University Press.

Crumbaugh, Justin. 2010. Destination Dictatorship: The Spectacle of Spain. Albany: State University of New York Press.

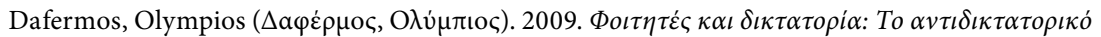

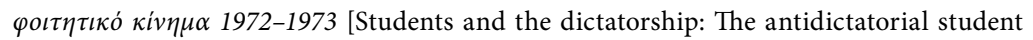
movement 1972-1973]. Athens: Gavriilidis.

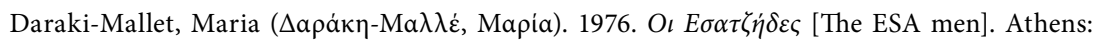
Kedros.

Derrida, Jacques. 1995. "Archive Fever: A Freudian Impression." Diacritics 25: 2, 9-63.

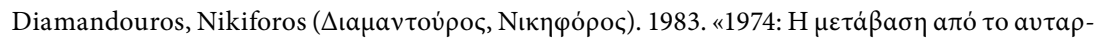

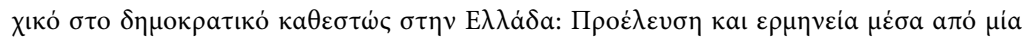

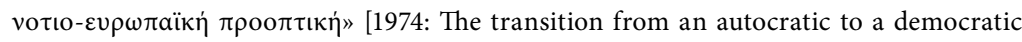
regime in Greece: Origins and interpretation from a Southern European perspective].

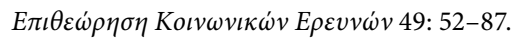

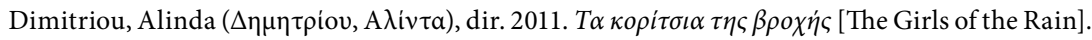

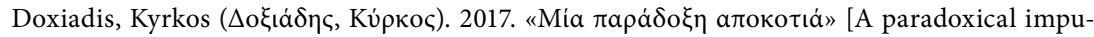
dence]. Efimerida ton Syntakton, 27 June.

Feitlowitz, Marguerite. [1998] 2011. A Lexicon of Terror: Argentina and the Legacies of Torture. New York: Oxford University Press.

Franco, Jean. 1984. “Self-Destructing Heroines.” Minnesota Review 22 (1): 105-115. 
2013. Cruel Modernity. Durham: Duke University Press.

Greenberg, Clement. 1939. “Avant-Garde and Kitsch.” Partisan Review 6 (5): 34-49.

Halbwachs, Maurice. 1952. Les cadres sociaux de la mémoire. Paris: Presses Universitaires de France.

Haritos-Fatouros, Mika. 2003. The Psychological Origins of Institutionalized Torture. London: Routledge.

Hartog, François. 2016. Regimes of Historicity: Presentism and Experiences of Time. Translated by Saskia Brown. New York: Columbia University Press.

Hirsch, Marianne. 2012. The Generation of Postmemory: Writing and Visual Culture After the Holocaust. New York: Columbia University Press.

Huyssen, Andreas. 2003. Present Pasts: Urban Palimpsests and the Politics of Memory. Stanford: Stanford University Press.

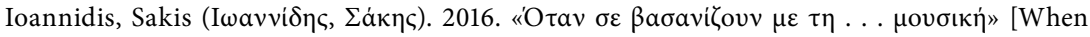
they torture you with ... music]. Kathimerini, 24 April. Accessed 2 May 2017. http://www .kathimerini.gr/857669/article/politismos/moysikh/otan-se-vasanizoyn-me-th-moysikh.

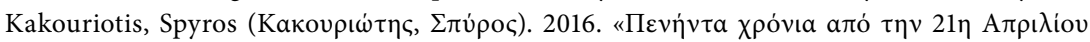

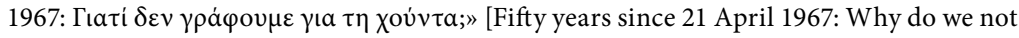

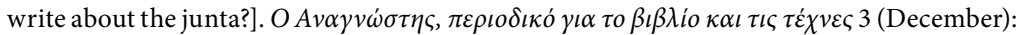
300-307.

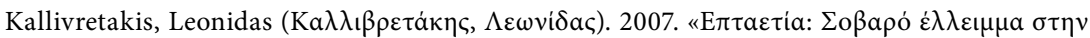

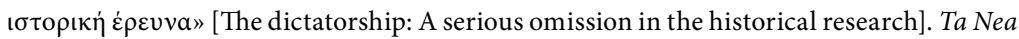
(Vivliodromio), 21 April.

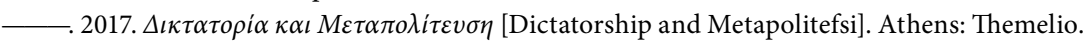

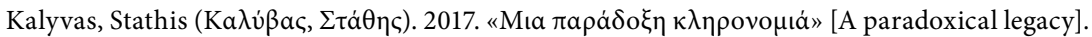
Kathimerini, 18 June.

Kambouridis, Haris, Daphne Koutsikou, and Christos Papoutsakis, eds. 1989. Kitsch Made in Greece. Athens: Friends of Anti Magazine.

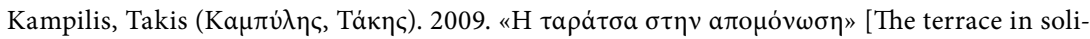

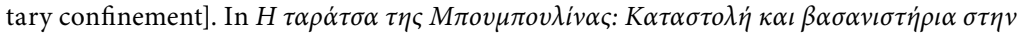

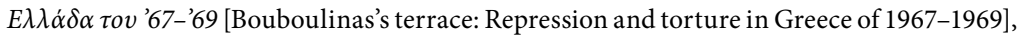
edited by Kostis Yiourgos, Takis Kampilis, and James Becket, 12-36. Athens: Potamos.

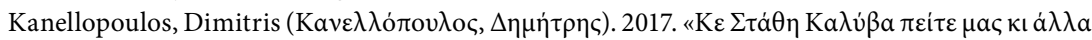

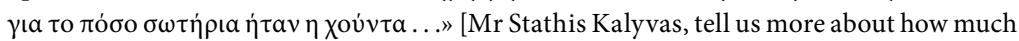
of a savior the junta was ... .]. Efimerida ton Syntakton, 19 June.

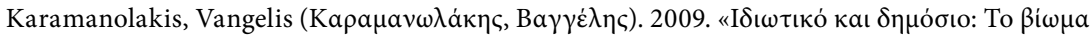

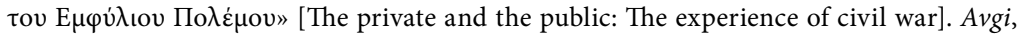
20 September.

, ed. 2010. H $\sigma \tau \rho \alpha \tau \iota \omega \tau \iota \kappa \dot{~} \delta \iota \kappa \tau \alpha \tau o \rho i \alpha$ 1967-1974 [The military dictatorship 1967-1974]. Athens: Ta Nea/History.

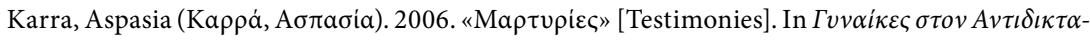

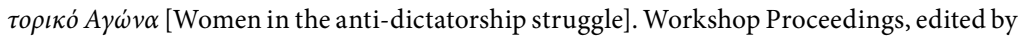

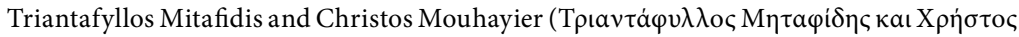
Movxá $ı ı \rho), 23-29$. Thessaloniki: Historical Archives Preservation Company (EDIA).

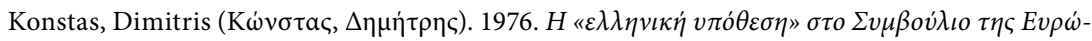

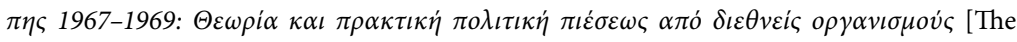


"Greek case" in the Council of Europe 1967-1969: Theory and practical politics of pressure by international organizations]. Athens: Papazisis.

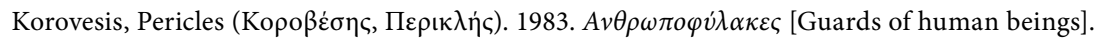
Athens: Kalvos.

Kornetis, Kostis. 2013. Children of the Dictatorship: Student Resistance, Cultural Politics and the "Long 1960s" in Greece. New York and Oxford: Berghahn Books.

2014a. "Public History vis-à-vis the Issue of Torture Under the Colonels' Regime in Greece." Ricerche Storiche 1: 81-100.

2014b. "From Politics to Nostalgia—and Back to Politics: Tracing the Shifts in the Filmic Depiction of the Greek 'Long 1960s' Over Time.” Historein 14: 89-102.

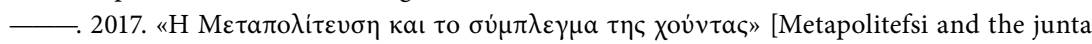
complex]. Ta Nea, 24 June.

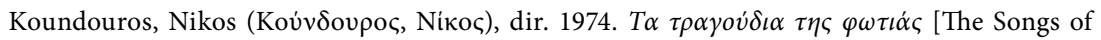
Fire]. Athens: Finos Film.

Kristeva, Julia. 1982. Powers of Horror: An Essay on Abjection. New York: Columbia University Press.

Kundera, Milan. 1984. The Unbearable Lightness of Being. New York: Harper and Row.

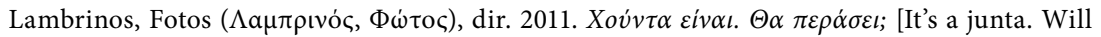
it pass?].

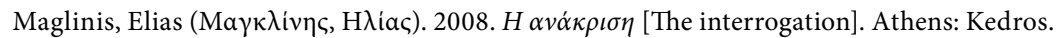

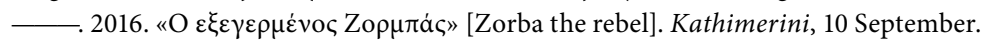

Maglinis, Elias. 2013. The Interrogation. Translated by Patricia Felisa Barbeito. Birmingham: Birmingham Modern Greek Translations.

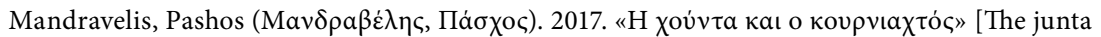
and the blinding dust]. Kathimerini 21 June.

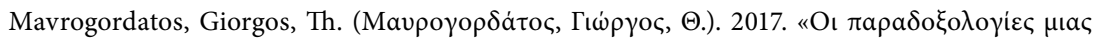

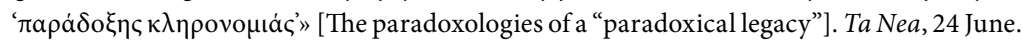

Mbembe, Achille. 2003. "Necropolitics." Translated by Libby Meintjes. Public Culture 15 (1): 11-40.

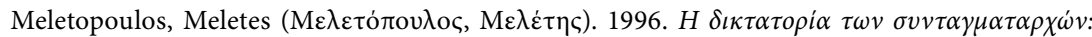

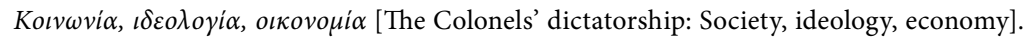
Athens: Papazisis.

Mouzelis, Nikos. 1978. Modern Greece: Facets of Underdevelopment. London: Macmillan.

Nafpliotis, Alexandros. 2013. Britain and the Greek Colonels: Accommodating the Junta in the Cold War. London: I.B. Tauris.

Neal, Arthur. 1998. National Trauma and Collective Memory: Major Events in the American Century. New York: M.E. Sharpe.

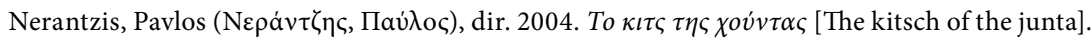
DVD. Thessaloniki: EPT 3.

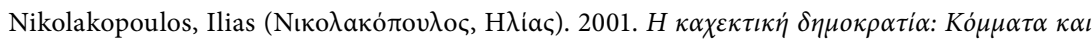

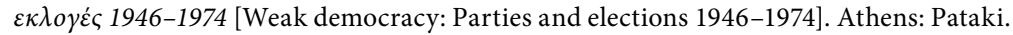

Nora, Pierre. 1989. "Between Memory and History: Les Lieux de Mémoire." Representations 26: $7-25$.

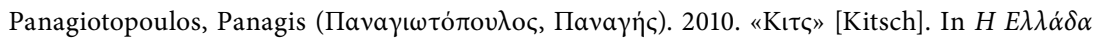

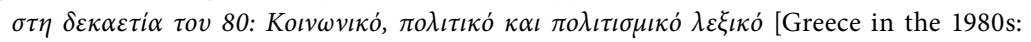


social, political, and cultural dictionary], edited by Vasilis Vamvakas and Panagis Pana-

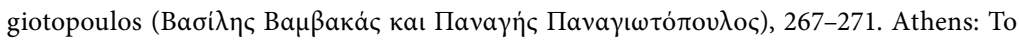
Perasma.

Panourgiá, Neni. 2009. Dangerous Citizens: The Greek Left and the Terror of the State. New York: Fordham University Press.

Papadogiannis, Nikolaos. 2015. Militant Around the Clock? Left-Wing Youth Politics, Leisure, and Sexuality in Post-Dictatorship Greece, 1974-1981. New York and Oxford: Berghahn Books.

Papaeti, Anna. 2013. "Music, Torture, Testimony: Reopening the Case of the Greek Junta (1967-1974)." The World of Music (new series): Music and Torture | Music and Punishment 2 (1): 67-89.

Papanikolaou, Dimitris. 2007. Singing Poets: Literature and Popular Music in France and Greece. Oxford: Legenda.

Partnoy, Alicia, 1998. The Little School: Tales of Disappearance and Survival. San Francisco: Midnight Editions.

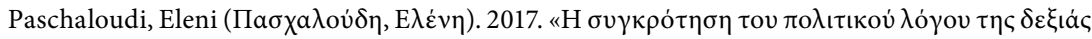

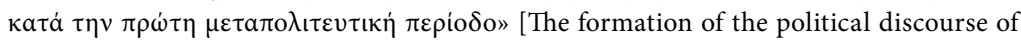

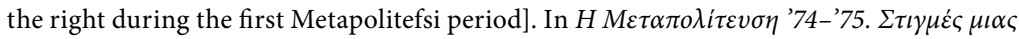
$\mu \varepsilon \tau \dot{\alpha} \beta \alpha \sigma \eta \varsigma$ [Metapolitefsi 1974-1975: Moments of a Transition], edited by Vangelis Karamanolakis, Ilias Nikolakopoulos, and Tasos Sakellaropoulos, 117-133. Athens: Themelio.

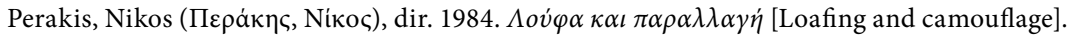

Puelo, Risa. 2017. "The Messy Politics of Documenta's Arrival in Athens." Hypoallergic, 10 April. Accessed 2 May 2017. https://hyperallergic.com/371252/the-messy-politics-of-documentas -arrival-in-athens/.

Pickering, Michael, and Emily Keightley. 2009. "Trauma, Discourse, and Communicative Limits." Critical Discourse Studies 6 (4): 237-249.

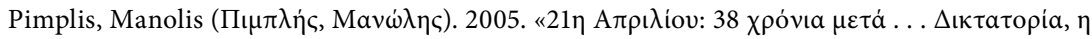

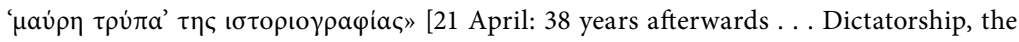
"black hole" of the historiography]. Ta Nea, 22 April.

Poulantzas, Nicos. 1976. The Crisis of the Dictatorships: Portugal, Greece, Spain. London: Humanities Press.

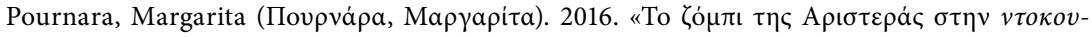
$\mu \varepsilon \dot{v} \tau \alpha »$ [The zombie of the left at documenta]. Kathimerini, 7 September. Accessed 2 May 2017. http://www.kathimerini.gr/873775/article/politismos/eikastika/to-zompi-ths -aristeras-sthn-ntokoymenta.

Pratt, Nicola. 2013. "Egyptian Women: Between Revolution, Counter-Revolution, and Orientalism." Jadaliyya, 6 May. Accessed 9 April 2017. http://www.jadaliyya.com/pages/index /11559/egyptian-women_between-revolution-counter-revoluti.

Raftopoulos, Dimitris. 1989. "Kitsch as a Fascism-Indicator." In Kitsch Made in Greece, edited by Haris Kambouridis, Daphne Koutsikou, and Christos Papoutsakis, 69-99. Athens: Friends of Anti Magazine.

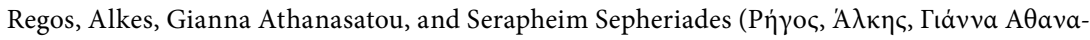

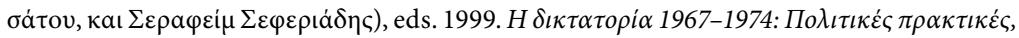

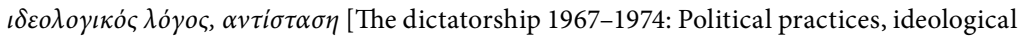
discourse, resistance]. Athens: Kastaniotis.

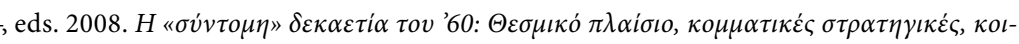

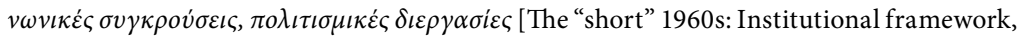
party strategies, social clashes, cultural processes]. Athens: Kastaniotis. 


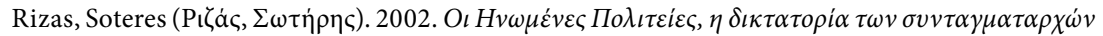

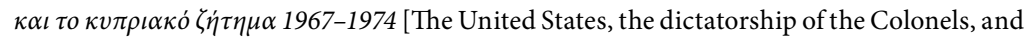
the Cyprus issue 1967-1974]. Athens: Patakis.

Ross, Kristin. 2002. May '68 and Its Afterlives. Chicago: Chicago University Press.

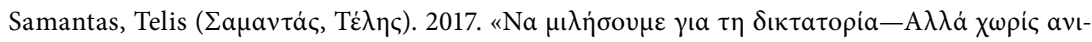

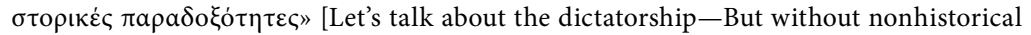
paradoxes]. DimArt (blog). 10 June. Accessed 27 June 2017. https://dimartblog.com/2017 /06/20/about-the-dictatorship-2/.

Silverstone, Roger. 2007. Media and Morality: On the Rise of the Mediapolis. Cambridge: Polity. Skordos, Adamantios. 2010. "Die Diktatur der Jahre 1967 bis 1974 in der griechischen und internationalen Historiographie." In Postdiktatorische Geschichtskulturen im Süden und Osten Europas: Bestandsaufnahme und Forschungsperspektiven, edited by Stefan Troebst, 123-205. Wallstein Verlag: Göttingen.

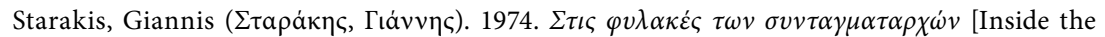

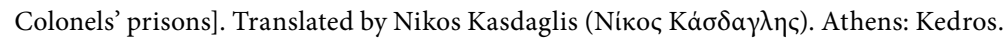

Stefatos, Katherine. 2012. "Engendering the Nation: Women, State Oppression and Political Violence in Post-War Greece (1946-1974).” PhD diss., Goldsmiths College, University of London. 2016a. "Subaltern Bodies: Gender Violence, Sexual Torture, and Political Repression During the Greek Military Dictatorship (1967-1974)." In Gender Violence in Peace and War: States of Complicity, edited by Victoria Sanford, Katerina Stefatos, and Cecilia Salvi, 19-33. New Brunswick and London: Rutgers University Press.

2016b. "Gendered Bodies of Aging: Women Exiles." Paper presented at the Aging and Its Tropes Workshop, Columbia University, 6-7 May.

Sturken, Marita. 2011. "Comfort, Irony, and Trivialization: The Mediation of Torture." International Journal of Cultural Studies 14 (4): 1-18.

Sutton, Barbara. 2007. "Poner el Cuerpo: Women's Embodiment and Political Resistance in Argentina." Latin American Politics and Society 49 (3): 129-162.

Taylor, Diana. 1997. Disappearing Acts: Spectacles of Gender and Nationalism in Argentina's "Dirty War." Durham and London: Duke University Press.

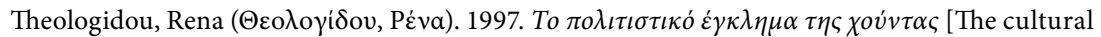
crime of the junta]. 0000006686. ERT Archive. Accessed 10 April 2017. http://archive.ert .gr/6686/.

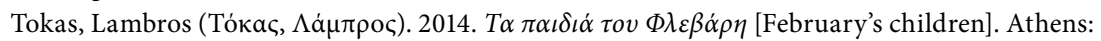
Kastaniotis.

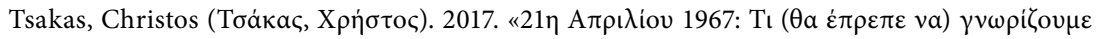

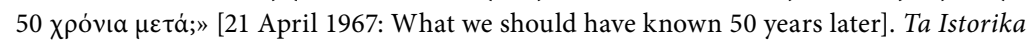
65 (April): 107-130.

Tsoucalas, Konstantinos. 1969. The Greek Tragedy. Harmondsworth: Penguin.

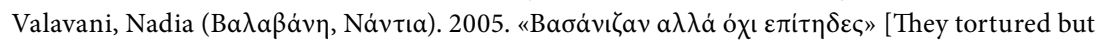
not on purpose]. Ta Nea, 29 November.

Van Dyck, Karen. 1998. Kassandra and the Censors: Greek Poetry since 1967. Ithaca and London: Cornell University Press.

Van Steen, Gonda. 2010. "Rallying the Nation: Sport and Spectacle Serving the Greek Dictatorships." The International Journal of the History of Sport 27 (12): 2121-2154.

2014. State of Emergency. Theater and Public Performance under the Greek Military Dictatorship of 1967-1974. Oxford: Oxford University Press. 


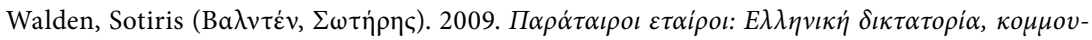

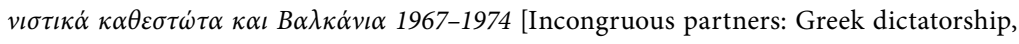
communist regimes, and the Balkans 1967-1974]. Athens: Polis.

Woodhouse, C.M. 1985. The Rise and Fall of the Greek Colonels. London and New York: Granada.

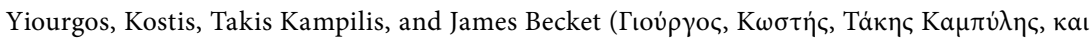

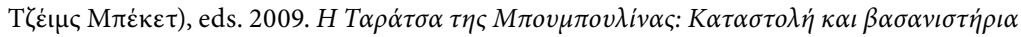
$\sigma \tau \eta v E \lambda \lambda \alpha \dot{\alpha} \alpha$ นov '67-'69 [Bouboulinas's terrace: Repression and torture in Greece of 1967-1969). Athens: Potamos.

Zengin, Asl. 2013. "What is Queer about Gezi?” Hot Spots, Cultural Anthropology (website). 31 October. Accessed 10 April. https://culanth.org/fieldsights/407-what-is-queer-about-gezi. 